\title{
Woman's Higher Education Phenomenon: Is It for A Good Life or Just Pride?
}

\author{
Rizky Fauziah
}

North Sumatera University, Medan, Indonesia

rizkyfauziahlbs@gmail.com

\begin{abstract}
It make the society paradigm changing named gender equality which let woman has the same right as man depend on their ability. It happens in every aspect including higher education. Woman earn and make higher education as their priority to improve their quality, but in the other side most of them take this just to upgrade their pride or social status. The existence of woman usually related to family or society, so it supposed to be the more educated woman the better the quality of their family/society will be. But now the people specially in Sumatera still lack of creative and critical thinking. This condition directs us to analyze the self-concept and self-awareness of higher educated woman who earn the master degree to find out why they study a lot but less changing happened.
\end{abstract}

Keywords: gender equality, higher education, self-awareness, self concept, woman

\section{INTRODUCTION}

Talking about woman, the higher educated woman, and woman's existence related to the self concept and self awareness itself. It's about the identity of woman who changed a lot since the gender equality. In Indonesia, higher educated woman is whom already finished the master degree program (S2). Education empower people include the woman. Based on the data of Direktorat Jenderal Pendidikan Tinggi Indonesia, in 2014 there are 239.339 women graduate on Bachelor's Degree, 18.560 women graduated from Master Degree, and 516 women who continue their education to doctoral level. This amount is big enough to show that higher educated woman in Indonesia does exist.

Generally, human beings have a picture or a personal view of themselves. This picture, which is called self-concept or self-image includes an overview of their appearance, physical health, abilities, weaknesses and behavior. Self-concept can be defined as a person's personal assessment oh themselves or rather, what they feel about their ability, past experiences and what they think lies ahead for them. To build self-concept, one also looks at the way he or she is viewed or judged by others. The perception of self and their environment through their senses and feelings about their ability to exude confidence and dignity also contributes to a person's definition of self- concept. Not only does self-concept include physical and psychological aspects but it can also relate to the experiences and knowledge acquired throughout their childhood ( $\mathrm{O}^{\prime}$ Connel, 2001).

In a research, Hormuth (2010) relates self-concept to self-assessment or selfperception. The concept largely represents the extent of an individual's faith in their own characteristics. This concept also reflects a person's judgement of themselves based on the way they weigh the importance of their success. Presscott (2006) defines self-concept as mental awareness, pre-conception and constant interest of oneself. Components of self-concept encompass the physical, psychological and social well-being of a person which can be influenced by attitude, habits, beliefs and ideas. These components can be summarized to form the concepts of self-image and general selfappreciation (Nasir and Lin, 2013).

Eckroth-Bucher (2010), defines the concept as "self-awareness involves the celebral exercise of introspection. This attribute reflects the cognitive exploration of own thoughts, feelings, beliefs, values, behaviors, and the feedback from others" (p.297). Self-awareness is getting to know about one self as a person and the important things in life which influences us in different ways. It also includes the reflection on how our attitude and belief can influence others. If we get the awareness of our own life then we can understand another 
person better. The concept is further elaborated by the authors; self awareness is the continuous process of understanding and knowing of one's own identity, beliefs, thoughts, traits, motivations, feeling, and behavior and to recognize how they affect others in different ways. In addition, it involves objectively examining one's personal beliefs, attitudes, strengths, and limitations (Boyd, 2005; Studart and Laaia, 2005). Thus all these literatures support the idea of self-evaluation and realizing why you behave the way you do, it also gives the dimension to explore oneself in different context and the way others reaction towards you. Self awareness to a greater extent gives satisfaction in life.

In general, self-awareness is important for personal growth; it helps an individual to manage self and to improve performance. It further helps in setting appropriate and realistic goals, and career and manage personal life stressors. But it first starts with the understanding and acknowledging of its importance in life. As Palmiere (2012), very well explains and justifies these points as:

Self-awareness is a core personality strength that can help us manage our businesses, our career and our lives. When we lack of selfawareness skills, we tend to make the same mistakes and encounter the same obstacles over and over again. But when we know where our unique strengths and limitations lie, we better equipped to face challenges, solve problems, choose our battle, make decisions, and predict the outcomes of those decisions.

Furthermore, this process helps in analyzing the difference and similarities between individuals. This will further help in developing interpersonal relationship and direct our communication towards other's need (Rasheed, 2015).

Some authors (Gergen, 1991; Gilligan, 1982; Nelson, 1996) had cited gender differences based on male/female personality traits, socialization differences, and expectations as possible obstacles for personal success. Gergen (1991) pointed out that in Gilligan's (1982) theory of ethics of caring, women had seen themselves as existing in a web of relationships held together by "bonds of caring". In Gilligan's (1982) descriptions, identity was combined in a context of relationship or in terms of a "social context". According to Wallace's (1994) study, certain perceived gender differences did not appear when comparing executive males and females. Wallace (1994) concluded that there was no consistent evidence that males and females differed in cognitive style, creativity, independence, general self-esteem, empathy, or sociability. However, it was noted that the impact of concept of self, confidence, and societal expectations affected one's self-esteem and thus one's successful endeavors. During the last few decades, research has shed light on the evolving self from a "strong stable or cohesive sense of self" to a self defined mostly by social relationships, and ultimately to a changing self, depending on a dynamic work environment to which one must adapt in order to survive (Powell, 2009).

According to the author experience as a double major master program student in Padang and Medan; also who worked at a university which dominated by higher educated lecturer; the woman identity become different from this phenomena. Kemdikbud data shows in 2012 there are 25.396 of woman who continue their study to Master Degree and Doctoral program. This numbers show that there is a big awareness of Sumatera's woman about higher education. But when this numbers compared to social quality or family quality it become nothing because less changing happened.

The numbers must be has an impact for society, particularly for woman who interact the most with their family, surroundings, or society. But it doesn't work properly because the higher educated woman divided into 2 groups, the one who continue their education for their life goodness and another one who continue their education for social pride. So it become important to discover how higher educated woman in Sumatera define their self-concept and self-awareness. By finding both of selfidentity, we will understand why the phenomena happened and why less changing happened.

\section{RESEARCH METHOD}

This research using qualitative method to discover how higher educated woman in Sumatera create their self-concept and self awareness about themselves. The research data base on depth interview to 4 people who 
represent higher educated woman and earn master degree (S-2). The informants are the alumnae of master program. 2 of them are married and 2 others still single.

Table 1. Informant List

\begin{tabular}{|c|c|c|c|c|}
\hline No. & Name & Status & University & Region \\
\hline 1. & WMK & Married & $\begin{array}{lr}\text { graduated } & \text { on } \\
2010 \quad \text { from } \\
\text { Universitas } \\
\text { Harapan Medan }\end{array}$ & $\begin{array}{l}\text { lived in Kisaran, } \\
\text { North Sumatera }\end{array}$ \\
\hline 2. & ESP & Single & $\begin{array}{lr}\text { graduated } & \text { on } \\
2011 \quad \text { from } \\
\text { Nommensen } \\
\text { University }\end{array}$ & $\begin{array}{l}\text { lived in } \\
\text { Pematang } \\
\text { Siantar, North } \\
\text { Sumatera }\end{array}$ \\
\hline 3. & NR & Married & $\begin{array}{l}\text { graduated on } \\
2016 \text { from } \\
\text { Universitas } \\
\text { Putra Indonesia } \\
\text { "YPTK" Padang }\end{array}$ & $\begin{array}{l}\text { lived in Bandar } \\
\text { Lampung, } \\
\text { Lampung }\end{array}$ \\
\hline 4. & FMY & Single & $\begin{array}{l}\text { graduated on } \\
2016 \text { from } \\
\text { Universitas } \\
\text { Putra Indonesia } \\
\text { "YPTK" Padang }\end{array}$ & $\begin{array}{ll}\text { lived in } \\
\text { Pekanbaru, Riau }\end{array}$ \\
\hline
\end{tabular}

The combination of informants purposed to get clear and better result. They are chosen to measure the real of self concept and self awareness of higher educated woman specially in Sumatera. They will be given several questions about what do they feel for being high educated woman among their family, surroundings, and society.

\section{RESULTS}

Components of self-concept encompass the physical, psychological and social wellbeing of a person which can be influenced by attitude, habits, beliefs and ideas. These components can be summarized to form the concepts of self-image and general selfappreciation (Nasir and Lin, 2013). The attitude, habits, beliefs, and ideas become the main tools to measure how the informants create their self concept. Here is the explanation:

\section{Self Concept}

The informants were given questions about how they interact with the society in the daily life. The questions such as what is the different that they found about their belief and ideas with the family, surroundings, and society; what do they think about their attitude; and what is their habit which make them different from others. From the married informant, they said that people mostly judge them as the super woman with high social class which make them treated like unusual part of society. They said that they prefer being quiet in daily life when facing different way of life. According to them, people mostly follow the 'traditions' in their life which contradicted with them who prefer use their knowledge to decide everything in their daily life. But it doesn't really matter for them because their degree is only for working life and when they come back to the family they're back just like another normal mother.

From the single informants, the answered is they feel the society see them as a career oriented women. They do not have time 
to do little talk with surroundings in the workdays, while they spend their weekend with some rest or activity with the family. They do not feel comfortable when being in the middle of society because they judged as the "high profile" person. The social gap between higher educated woman with the society become serious problem because it affect the communication between them, even the nonverbal communication.

Overall, we can see that higher educated woman face the different perception with their surroundings. Gender equality is work slowly for Sumatera society. They prefer being quiet in order to respect others even being judged as high profile person eventually. The higher educated woman see themselves as skeptical person that put their knowledge first to decide everything in their daily life.

\section{Self Awareness}

The self awareness is used to know how the informants solve problem that they get from interact with the people. Self-awareness is getting to know about one self as a person

\section{CONCLUSION}

From the explanation about self concept and self awareness of higher educated woman in Sumatera, we can conclude that:

1. The self concept and self awareness is shaped by the knowledge background and social construction. Education and communication gap between higher educated woman with the society affect the misperception among them.

\section{REFERENCE}

Rasheed Parven, Subia. (2015). "Self Awareness as a Therapeutic Tool for Nurse/ Client Relationship", International Journal of Caring Sciences, Vol. 8 No. 1.

Nasir and Lin. (2013). "The Relationship between Self-Concept and Career Awareness amongst Students", Asian Social Science, Vol. 9 No. 1.

Powell, Katherine C. (2009), "The Role of Concept of Self and Societal and the important things in life which influences us in different ways. It also includes the reflection on how our attitude and belief can influence others. If we get the awareness of our own life then we can understand another person better (Rasheed, 2015).

From the informants, they mostly said that they ignore every denial expression from society or others. They think that it's just a normal phase and they focused on their career for better future. The higher education woman rejected to be engage to the society and do not feel responsible to change the society. They think because they already fight for their degree then they deserve to work as good as they can to have better life quality.

Unique point that found in the interview is the feeling of being ignored in the society. The women said that Sumatra people still put the man in the first line and decision making must be done by the man. The higher educated woman think that it's better for them to just do their business and ignore the other because they know it's not their right to be involve in the society.

2. The different way in showing respect to others become serious problem because everyone prefer being quiet and stand with their own point. Communication can not working properly because of the negative thinking of each other since they can not understand what is really happening.

3. Gender equality is working slowly in Sumatera. The existence of woman in society still can not accepted since they are used to put man first.

Expectations in Academic and Career Achievement", Journal of Adult Education. Vol. 38 No. 2.

Tabloid Nova. (2015), "Perempuan Peneliti di Indonesia Kalah dibandingkan Negara Berkembang Lain", available at www.tabloidnova.com (accessed 14 November 2016).

Kemendikbud. (2012). "Number of Students by Program, Sex, and Province of Higher Education Academic Year: 2011/2012", available at www.kemdikbud.go.id (accessed 14 November 2016). 